\title{
The Effect of TFRS 16 Leases Standard on Financial Indicators of Turkish Retailer Companies
}

\author{
Erkin Nevzat GÜDELCi ${ }^{1}$
}

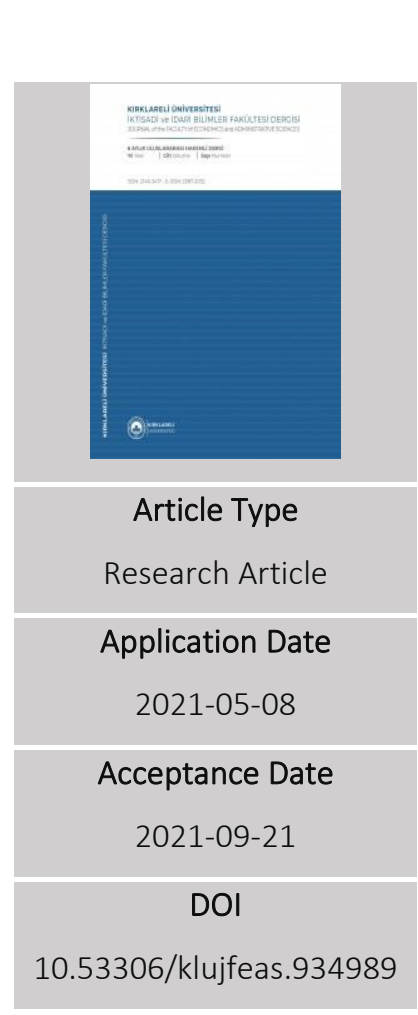

\begin{abstract}
The IASB (International Accounting Standards Board) abolished the IAS 17 Standard, which has been in force for 30 years, and replaced it with the IFRS 16 Standard for leasing transactions at the end of a 10year study. The same standard came into force in January 2019 with the name of TFRS 16 Leases Standard in Turkey. The TFRS 16 Standard has radically eliminated the accounting approach applied with the TMS 17 Standard which is based on the financial and operating lease distinction. In this way, it has been tried to ensure that the financial statements of the enterprises can be prepared more accurately. With the TFRS 16 Standard, lessees are required to specify assets related to operating leases as right-to-use assets and liabilities as lease liabilities in statement of financial position. The radical change brought about by TFRS 16 Standard is expected to have an impact on the financial statements of the companies. The purpose of this study is to reveal how the financial indicators of the enterprises have been affected with TFRS 16 and to evaluate the financial impact created by TFRS 16 on a sectoral basis. For this purpose, the 2018 and 2019 financial indicators of the businesses operating in the retailer sector were compared using the MannWhitney $U$ test. As a result of the analysis, no statistical difference was detected between the periods before and after TFRS 16 in terms of financial indicators.
\end{abstract}

Key words: financial indicators, TFRS 16, operational leasing

1 Assist. Prof., Batman University, Faculty of Economics and Administrative Sciences, Business Department, erkingudelci2@hotmail.com, ORCID: 0000-0002-4163-7433 


\title{
TFRS 16 Kiralamalar Standardının Türk Perakende İsletmelerinin Finansal Göstergelerine Etkisi
}

\author{
Erkin Nevzat GÜDELCi
}

Öz

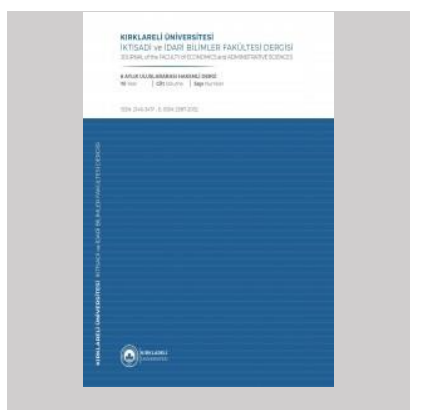

Makale Türü

Araştırma Makalesi

Başvuru Tarihi

08.05.2021

Kabul Tarihi

21.09.2021

DOI

10.53306/klujfeas.934989
IASB (Uluslararası Muhasebe Standartları Kurulu), 30 yıldır yürürlükte olan UMS 17 Standardını 10 yıllık bir çalışmanın sonunda yürürlükten kaldırmış ve yerine kiralama işlemleri için UFRS 16 Standardı getirmiştir. Aynı standart, Türkiye'de TFRS 16 Kiralama Standardı adıyla Ocak 2019'da yürürlüğe girmiştir. TFRS 16 Standardı, finansal kiralama ve faaliyet kiralaması ayrımına dayanan TMS 17 Standardı ile uygulanan muhasebe yaklaşımını kökten ortadan kaldırmıştır. Bu sayede işletmelerin finansal tablolarının daha doğru bir şekilde hazırlanabilmesi sağlanmaya çalışılmıştır. TFRS 16 Standardı ile kiracıların, faaliyet kiralamalarına ilişkin varlıkları kullanım hakkı varlıklar, borçları ise finansal durum tablosunda kiralama borçları olarak belirtmeleri gerekmektedir. TFRS 16 Standardının getirdiği köklü değişikliğin şirketlerin finansal tablolarını da etkilemesi beklenmektedir. Bu çalışmanın amacı, işletmelerin finansal göstergelerinin TFRS 16 ile nasıl etkilendiğini ortaya koymak ve TFRS 16 'nın yarattığı finansal etkiyi sektörel bazda değerlendirmektir. Bu amaçla perakende sektöründe faaliyet gösteren işletmelerin 2018 ve 2019 mali göstergeleri Mann-Whitney $U$ testi kullanılarak karşılaştırılmıştır. Analiz sonucunda finansal göstergeler açısından TFRS 16 öncesi ve sonrası dönemler arasında istatistiksel bir farklılık tespit edilememiştir.

Anahtar sözcükler: TFRS 16, Finansal Göstergeler, Faaliyet Kiralaması

2 Dr. Öğr.Üyesi, Batman Üniversitesi, İ̈BB, İşletme Bölümü, erkingudelci2@ hotmail.com, ORCID: 0000-0002-41637433 


\section{Introduction}

Leases are mainly divided into financial and operational leases. In financial leasing, all risk and income are transferred to the lessee, on the other hand in operating leasing, the risk and return remains with the lessor. Therefore, TMS 17 Leasing Transactions Standard indicates that the assets and liabilities about financial leasing transactions should be included in the financial statements, whereas the transactions related to the operating lease should not be reflected in the financial statements (Gökgöz, 2019, p. 320). However, the fact that operational leasing transactions are not included in the financial statements prevents information users from accessing complete and accurate financial information (ISMMMO, 2019, p. 20). The principal objective of TFRS / TMS (Turkey Financial Reporting Standards /Turkey Accounting Standards) is to increase the comparability and quality of financial information and olso present true information for investors, creditors and other users to take right economic decisions (KGK, 2018, p. 5). As a result of the survey conducted by the IASB (International Accounting Standards Board) to evaluate the effect of operating lease transactions on the financial statements of 30,000 enterprises in 2015, it was determined that the total liability of 2.86 trillion dollars related to the operating lease was not reflected in the financial statements. Similarly, the SEC (American Securities and Exchange Commission) determined that the liabilities for operating leases not reflected in the financial statements of American enterprises in 2005 were 1.25 trillion dollars (Magli etc., 2018, p. 77). The operating leases can reach significant amounts and the fact that they are not included in the financial statements causes the debts of the enterprises not to be evaluated correctly for the investors. In addition many assets that can generate income for the tenants are not shown in the financial statements (Gökgöz, 2019, p. 320; iSMMMO, 2019, p. 23).

After the pressures from enterprises, especially airlines, transport companies, chain retailers and service-intensive businesses, the IASB initiated a project to eliminate the deficiencies in the IAS 17 Standard and put IFRS 16 Leasing Standard into effect instead of IAS 17. New standart started to be implemented from January 2019 (ISMMMO, 2019, p. 20). Similarly, on January 12019 IAS 17 Leases Standard were removed in Turkey and IFRS 16 standard was introduced instead (Gökgöz, 2019, p. 320). TFRS 16 Leases Standard states that financial leasing transactions must be reflected in the lessee's financial statements regardless of financial or operating lease. With the new standard, the right-to-use will be included in the financial statement of the enterprise rather than asset itself,, on the other hand, debts arising from the right to use will be shown in the financial statement as lease debt (Diaz and Ramirez, 2018, p. 106; ISMMMO, 2019, p. 23). With TFRS 16, it is expected that the reflection of operating leasing transactions as new assets and liabilities in the financial statements will create much financial differences (Diaz and Ramirez, 2018, p. 106). Evaluating the possible financial impacts of the new standard will provide useful information for relevant parties, especially for those that frequently prefer financial leasing as a financing method.

The purpose of this study is to examine the effect of financial leasing transactions on financial statements after the TFRS 16 standard through financial indicators. In this context, 
the retail sector, which is seen as one of the sectors that will be most affected financially in the impact report of the IASB, has been investigated. 12 companies in the retail sector operating in BIST (İstanbul Stock Market) were included in this study. As a result of the analysis, it was concluded that although there were differences between before and after TFRS 16 in terms of certain financial indicators, these differences seem to be not statistically significant for any indicator.

\section{Conceptual Framework}

IAS 17 Leasing Transactions Standard has been criticized for a long time because it does not allow the assets and the liabilities of financial leasing contracts to be adequately reflected in the financial statements, IAS 17 could not provide enough transparent information about financial statements to analysts, investors and other segments (Sacarin, 2017, p. 115). In IAS 17, tenants recognized the transactions related to operating leases as expenses on an accrual basis and did not include liabilities regarding lease payments for future operating leases (Magli etc., 2018, p. 77).

Business managers could prefer operating leasing more. Because it allows the debt and profitability ratios of the enterprises to appear better. In 2016, when the IAS 17 standard was in effect, the total lease of all enterprises worldwide was around 3 trillion. $85 \%$ of this total belongs to the operating lease and was not reflected in the financial statements. However, it was observed that these enterprises, which tend to operate leasing a lot during the financial crisis, have difficulty in adapting to the changing economic realities. Although the long-term liabilities of these entities for leasing transactions were dozens of times greater than they appeared, their financial statements still looked well. This prevented the correct evaluation (Hoogervorst, 2016, p. 2).

Interested parties, who had wanted to make sound financial comparisons between enterprises, were trying to adapt the information in the footnotes in the financial statements regarding the operating lease. However, this situation caused additional costs and also a higher determination of the debt amount. While the liabilities related to financial leasing were shown with amortized present value in the statement of financial position, liabilities related to operating lease was included in footnotes with non-amortized value. Therefore, the related parties demanded the elimination of financial and operating lease distinction and transition to a single accounting application (Sacarin, 2017, p. 115; Bunea, 2017, p. 251).

The IASB abolished the IAS 17 standard due to its inconveniences and replaced it with the IFRS 16 standard, which allows all leases to be included in the statement (Giner and Pardo, 2018, p. 496). TFRS 16 standard came into force on Junuary 1,2019 in Turkey. With TFRS 16 , the separation of financial and operating leases for long-term lease contracts was eliminated and the transactions related to operating leases were reflected in the financial statements (Sari et al., 2016, p. 139). In this way, it was ensured that the elements included in the definition of assets and liabilities specified in the conceptual framework will be reflected in the financial statements (Magli etc., 2018, p. 77). After the TFRS 16, enterprises that choose financial leasing will reflect the right of use and lease obligations arising from a 
lease agreement more than 12 months to the statement of financial position. The Board stated that the rights of use of financial leasing should be accounted for as tangible fixed assets based on the principle of "asset is the sum of rights". In addition, the depreciation and interest costs of the asset in the profit or loss statement will also be separated (Deloitte, 2017; Bunea, 2017, p. 251). According to TMS 17, the transfer of all kinds of risks and benefits raised from the ownership of the asset is required in order to account for the transactions. However, according to TFRS 16, the transfer of the right of use for a certain period of time is important. Here, before deciding whether or not to transfer the right to use the asset, it is necessary to obtain almost all of the economic benefits arising from the use of the asset and to have the right to manage the asset (TFRS 16, article. 21).

TFRS 16 states that assets and liabilities not shown previously should be reflected in the financial statements but this won't do any difference for lessor. With the TFRS 16 standard, it is expected that enterprises with significant operating leases (retail businesses, air and road transport companies, etc.) will experience an increase in their assets and liabilities and a decrease in equity. Therefore, with the TFRS 16 standard, it is thought that the financial indicators will be significantly affected (Sacarin, 2017, p. 116). With the TFRS 16 standard, it is expected that the financial status statement will grow, while the leverage and capital ratios will be adversely affected. In addition, the application of TFRS 16 standard is expected to have an effect on other financial and performance indicators. Financial measures emerging after TFRS 16 will affect many existing regulations and business-related segments (PWC, 2016). The effects of the standards on the financial statements are not limited to the statement of financial position. The nature of the expenses is changing for companies which have lots of off-balance sheet lease contract elements. This causes other financial statements to be affected (Deloitte, 2017, p. 49).

- The impact on the Statement of Financial Position

The biggest change brought by TFRS 16 is the reflection of operating lease transactions in the statement of financial position. With new standard, instead of the leased assets, the rights to use them are included in the statement of financial position, while the debts arising from the usage rights are included as liabilities in the statement of financial position (ISMMMO, 2019, p. 23). Exceptionally, there is no obligation to reflect leases with less than 12 months and leases of immaterial assets in the statement of financial position (Yürekli, 2019, p. 143). It is expected that the total assets and liabilities of the enterprises that frequently use operating leasing will increase, while their equity capital will decrease. The reason for the expectation of decrease in equity is that the depreciation amount allocated according to the normal depreciation method for the asset does not change, whereas the interest component decreases at the beginning of the lease period (Acar et al., 2017, p. 599). The effect on equity is considered to vary depending on the tenant's leverage, the conditions related to leasing, the ratio of debts to equity, and how the tenant finances its activities (Engin, 2016, p. 32). 
Table 1. The Effect of IFRS 16 on the Statement of Financial Position

\begin{tabular}{|c|c|c|c|}
\hline \multirow[b]{2}{*}{ Elements } & \multicolumn{2}{|c|}{ TMS 17} & IFRS 16 \\
\hline & $\begin{array}{c}\text { Financial } \\
\text { Leasing }\end{array}$ & $\begin{array}{l}\text { Operational } \\
\text { Leasing }\end{array}$ & (All leasing types) \\
\hline $\begin{array}{l}\text { Reflection of Assets in the } \\
\text { Statement of Financial } \\
\text { Position }\end{array}$ & Yes & No & $\begin{array}{l}\text { Assets Reflected in the } \\
\text { Statement of Financial Position }\end{array}$ \\
\hline $\begin{array}{l}\text { Reflection of Liabilities in } \\
\text { the Statement of Financial } \\
\text { Position }\end{array}$ & Yes & No 2 & $\begin{array}{l}\text { Liabilities Reflected in the } \\
\text { Statement of Financial Position }\end{array}$ \\
\hline $\begin{array}{l}\text { Off-Balance Sheet Rights } \\
\text { and Obligations }\end{array}$ & No & Yes & No \\
\hline
\end{tabular}

Reference: Sacarin, 2017, p. 116

- The Effect on Profit or Loss and Other Comprehensive Income Statement

According to TFRS 16, the total value of the expenses arising from financial leasing is the same as the total value of the expense for the entire lease period according to TMS 17. However, the value and structure of expenses for each reporting period differ between both standards (Sacarin, 2017, p. 116). According to TMS 17, lease payments for operating leases are considered as operating expenses, while depreciation arising from the right to use and interest expenses for debt payments must be reported separately in accordance with TFRS 16 (ISMMMO, 2019, p. 23). With TFRS 16, companies report interest expense as financing expense and depreciation expense as depreciation of tangible fixed assets (Acar, et al., 2017, p. 599). Presenting lease-related liabilities separately from other financial liabilities enables users of financial statements to see the liabilities arising from lease agreements (IASB, 2016, p. 61). Therefore, with TFRS 16, operating expenses related to leasing transactions will not be reported, but interest and depreciation expenses will be reported (Engin, 2016, p. 32). As a result, it is expected that there will be an increase in EBITDA (earnings before interest, tax, depreciation), operating profit, financial expenses and fixed profit before tax (iSMMMO, 2019, p. 24).

- The Effect on Cash Flow Statement

TFRS 16 application has no effect on cash flows. However, the structure of cash flows in the cash flow statement will change. With the new standard, cash flows from activities will decrease, while cash flows from financing activities will increase. However, cash flows will not change in total (Acar et al., 2017, p. 600; iSMMMO, 2019, p. 25; Sacarin, 2017, p. 116).

\section{Literature Review}

In the literature, there are many studies examining the effect of IFRS 16 on financial statements and financial indicators. Most of these studies use the "Constructive Method". Diaz and Ramirez (2018) conducted a study on 646 European companies using the 
constructive method. As a result of their studies, they determined that the new standard will have a significant impact on financial ratios, similar to the results in the literature. In another study using the construvtive method, Sacarın (2017) tried to determine the effect of IFRS 16 application on financial statements and financial determinants through a case study. As a result of the study, it was determined that while some proportions differ with the new application, there will be no change in some.

Magli et al., (2018) discussed how the financial performance and financial leverage of businesses will be affected by IFRS 16 on a sectoral basis. In their studies, the future financial information of 113 companies in Italy was examined. As a result of their studies, they reached the conclusion that the enterprises will be affected differently from the new standard according to the sectors. Tanese et al. (2018) discussed the effect of IFRS 16 Leasing Standard on the basic financial statements of the companies. As a result of their studies, they concluded that the financial statements of the companies will be affected differently according to the sector they are in. In his study, You (2017) analyzed the data of 31 airlines around the world between 2013 and 2015 using the costructive method. As a result of his study, he determined that the liabilities in the financial statements of airline companies will increase by $30.68 \%$. In addition, with the new standard, it has come to the conclusion that the financial rates related to the financial statements of the enterprise will differ. Similarly, Veverkova (2019) examined how the financial statements of 15 airlines operating in Europe will be affected by IFRS 16. As a result of his work, it has been determined that the statement of financial position and other comprehensive income statement will be significantly affected. In another study conducted on airline companies, Alabood et al. (2019) examined the effect of IFRS 16 on financial statements and ratios by using the data obtained from the financial statements in the annual reports of three airline companies operating in the Middle East. As a result of their studies, it was concluded that the financial ratios of airline companies will be affected significantly and these companies will experience adaptation problems. Levanti (2019) determined the changes brought about by IFRS 16 in his study. In his study, it was tried to determine the effects of these changes through the financial statements of the five largest banks operating in Romania.

In their studies, Giner and Pardo (2018) examined whether there would be an impact on the pricing decisions of investors if operating leasing transactions were reflected in the financial statements in an environment that has not been examined before. They used the footnotes of financial leasing statements of the Spanish companies. As a result of the analysis, no difference was found between the investors in rule-based countries with less developed markets and the investor behavior of the principle-based countries with more developed markets. Therefore, with the new standard, it has been concluded that most affected the industries will not have a significant impact on the stock market. Quach and Tu (2020) focused on how IFRS 16 might affect the quality of financial statements during the transition period. In this context, they took 17 businesses operating in the retail sector on the Nasdaq stock exchange. As a result of their studies, it has been concluded that the enterprises are unwilling to reflect the effects of the new standard on their financial statements. In their studies, Spanberger and Rista (2020) investigated how the financial statements of 279 enterprises in 11 sectors in Switzerland are affected by IFRS 16 and what 
kind of effects they will have for financial statement users. As a result of their study, they determined that the biggest change in financial statements was on the customer service sector and the least impact was on the financial sector. In his study, Kramarova (2020) evaluated comparatively the effects of leasing transactions on financial reporting between Slovak national accounting standards and IFRS 16. At the end of his study, he concluded that there are differences between the two standards for lease transactions. Hladika and Valenta (2018) tried to explain how IFRS 16 affects the information presented in the financial statements through a case study. Their studies revealed that the new standard would provide more accurate information for tenants, investors and users of financial statements in assessing the positions of businesses. In their study, Todorova and Sokolova (2019) evaluated what the general future impacts could have on businesses with IFRS 16. They benefited from the results of other studies on the subject in their studies. With their studies, it has been concluded that the enterprises with a high ratio of total operating lease cost to total liabilities are the enterprises that will be most affected financially.

Öztürk and Serçemeli (2016) discussed the effects of TFRS 16 on the basic financial statement ratios of tenant enterprises with a case study they conducted on an airline business. As a result of their studies, it has been concluded that the operating lease has a significant financial impact on the assets and liabilities in the statement of financial position. Sarı et al. (2016) similarly discussed the effect of TFRS 16 on financial statements and financial ratios. In their studies, they evaluated how seven retail businesses operating in Borsa Istanbul would be affected by the new standard by using the costructive method. As a result of their studies, it has been concluded that the new standard will have a statistically significant effect on financial ratios. In his study, Hazır (2019) discussed how different accounting policies can be prevented by inside group transactions related to financial performance. In addition, it compared the standard applications of TFRS 16 and TMS 17 with each other. Akdoğan and Doğan (2020) conducted a study on 7 retail companies in order to see the financial changes that will occur with the TFRS 16 standard. By considering the 2018 period-end financial statements of these companies, the effect of the new standard on the financial statements and ratios has been tried to be determined. As a result of their work, the net working capital and liquidity ratios decreased, whereas the financial leverage ratio increased. Sarı and Güngör (2020) tried to determine the financial effects that will arise with the implementation of TFRS 16 standard by using the financial statement footnotes of the 12 enterprises. As a result of their studies, it has been concluded that the financial statement items and ratios will change significantly as expected. Özdoğan and Uygun (2020) examined the enterprises on a sectoral basis with the impact analysis report of the IASB in order to reveal the differences between TMS 17 and TFRS 16. It has been determined that the sectors that will be most affected during the transition to TFRS 16 will be companies in the retail, aviation and health sector. Akbulut (2018) examined the effect of TFRS 16 standard on financial statements and rates by using financial data from 2015 and 2016 through Turkcell company. As a result of the study, it was determined that total assets and total liabilities increased each year, on the other hand, total equity decreased. 


\section{Metadology Of The Work}

\section{1. The Subject of The Study}

"TFRS 16 Leases Standard" was published in the Turkish Official Joural Instead of "TMS 17 Leasing Standards", and entered into force on 01.01.2019. Operating lease transactions that were not reflected in the financial statements in the previous standard have started to be shown in the financial statements with this new standard. Therefore, it is considered that the financial statements and financial indicators of the enterprises will be affected significantly with the new standard, it is thought that with TFRS 16, one of the sectors whose financial indicators will be affected the most will be retailor sector (PWC, 2016).

The subject of this study is the effect of TFRS 16 on the financial indicators of retail companies. Therefore, in this study, 12 retail companies operating in Istanbul Stock Exchange (BIST) were included. Only 12 companies data can be accessed through activity reports for the year 2018 and 2019.

\subsection{The Aim of The Study}

The purpose of this study is to reveal how TFRS 16 affects the financial indicators of retail businesses quantitatively compared to the previously effective TMS 17 standard. Another purpose of this study is to try to determine whether the results of this study will be similar to the results of the studies in the literature which were trying to determine the future financial effects of TFRS 16 standard.

\subsection{Method and Application of The Study}

In order to determine the effect of TFRS 16 standard on the financial indicators of retail companies, the data from the financial statements of the enterprises for 2018 and 2019 were used. In this study, the effect of TFRS 16 on the financial indicators has been tried to be determined. In this study, In order to determine the effect of TFRS 16, the financial data before and after TFRS 16 were compared using the Mann-Whitney $U$ test. Mann-Whitney $U$ test is used to compare if there is a difference in the dependent variable for two independent groups (www.sheffield.ac.uk. access date: 09.17.2021). Mann-Whitney U test is a non-parametric test. Non-parametric tests are used when there is no or little information about the universe. One of the reasons to use these tests is if sampling is too small to rely on regarding the whole universe. Therefore, non-parametric Mann-Whitney $U$ test had to be applied in this work rather than its stronger counterpart parametric test (islamoğlu and Alnıaçık, 2016, p. 458).

In order to put the financial effect of IFRS 16 clearly on retailer companies, financial indicators which are expected to be mostly effected were chosen. In literature it is seen that there isn't a consensus among researchers about which financial indicator set exactly should be used. In this work, most common financial indicators in literature were chosen. The impact expectation of TFRS 16 on financial indicators are summarized in Table 2. (IFRS, 2016; Gökten and Kurnaz, 2020; Parlak, 2018; Sarı et al. 2016). 
Table 2. Impact Expectation of TFRS 16 on Financial Statement

\begin{tabular}{|c|c|c|}
\hline Financial Indicators & Expectation & Explanations \\
\hline $\begin{array}{l}\text { The Size of the } \\
\text { Statement of } \\
\text { Financial Position }\end{array}$ & Increase & $\begin{array}{l}\text { An increase is expected since the operating } \\
\text { lease amounts will be reflected in the } \\
\text { statement of financial position. }\end{array}$ \\
\hline Operating Expense & Decrease & $\begin{array}{c}\text { Operating expenses are expected to } \\
\text { decrease since financial lease amounts will } \\
\text { not be written as operating expenses. }\end{array}$ \\
\hline Financing Expenses & Increase & $\begin{array}{l}\text { An increase is expected since the liabilities } \\
\text { of operating lease will be reflected in the } \\
\text { statement of financial position. }\end{array}$ \\
\hline Asset Turnover Rate & Decrease & $\begin{array}{l}\text { As rental assets are considered as part of } \\
\text { total assets, they are expected to decrease. }\end{array}$ \\
\hline $\begin{array}{l}\text { Financial Leverage } \\
\text { Ratio }\end{array}$ & Increase & $\begin{array}{l}\text { It is expected to increase as the financial } \\
\text { liability increases. }\end{array}$ \\
\hline $\begin{array}{l}\text { Return of Assets } \\
\text { (ROA) }\end{array}$ & Decrease & $\begin{array}{l}\text { Decrease is expected as lease right is } \\
\text { included as part of total assets }\end{array}$ \\
\hline Debt Equity Ratio & Increase & $\begin{array}{c}\text { An increase is expected as the liabilities will } \\
\text { increase. }\end{array}$ \\
\hline
\end{tabular}

In order to determine the change created by TFRS 16 on financial indicators, it was aimed to demonstrate the financial changes by comparing the 2018 data when the TMS 17 standard is in effect, with the 2019 data after the TFRS 16 standard came into force. In order to determine these changes, the Mann-Whitney $U$ test, which is one of the descriptive and non-parametric analyzes, was applied to the data of the enterprises in the sector.

\section{4. The Findings of The Study}

According to the results of the IASB impact analysis report, certain financial ratios of enterprises are expected to improve, while some financial ratios are expected to deteriorate (IFRS, 2016). In this study, analyzes were carried out to determine whether 12 companies operating in the retail sector experienced changes as expected in Table 2 with TFRS 16.

The $\log 10$ values were used for the size of the statement of financial position, operating expense and financial expense data to make these values more suitable for analysis. First, the average end-of-term financial statement indicators of 12 retail companies were analyzed comparatively with the pre-2018 TFRS 16 period and the year 2019 when TFRS 16 entered into force. Descriptive analyzes were used first to make these comparisons. Then Mann-Whitney $U$ were used to see if the difference is meaningfull. In Table 3, first the effect of TFRS 16 on the size of the statement of financial position has been analyzed. 
Table 3. Analysis of TFRS 16 impact on The Size of The Statement of Financial Position

\begin{tabular}{cccc}
\hline & Mean & Minimum & Maximum \\
\hline 2018 & 7,7802 & 5,88 & 9,51 \\
2019 & 7,9381 & 6,13 & 9,76 \\
\hline
\end{tabular}

When the sector data of 12 retail companies are analyzed, it is seen that the size of the statement of financial position increased after TFRS 16 . This situation is in line with the expectations in the Table 2 that the statement of financial position will grow as a result of capitalization of lease payments with TFRS 16 . With the transition to IFRS 16 , operating leases has started to be reported in the financial statements. As a result, it is expected that the size of the statement of financial position will grow. However, Mann-Whitney $U$ test was conducted to determine whether the difference was significant or not and it was concluded that the difference between 2018 and 2019 was not significant $(U=49.00, p=$ $0.450>0.05)$. Therefore, there is no statistical difference when comparing the years before and after TFRS 16. Parlak (2018) and Döğüş and Üçoğlu (2021) also found that with the arrival of the TFRS 16, there would not be a significant change in the size of the statement of financial position for retailer sector. Table 4 includes the analysis of the impact of TFRS 16 on operating expenses.

Table 4. Analysis TFRS 16 Impact on Operating Expenses

\begin{tabular}{cccc}
\hline & Mean & Minimum & Maximum \\
\hline 2018 & 7,2983 & 5,22 & 9,48 \\
2019 & 7,3159 & 5,07 & 9,54 \\
\hline
\end{tabular}

With TFRS 16, operating leases are not classified as operating expense, but instead It is recognized as depreciation and interest expense. Therefore it is expected that operating expense will decrease between 2018 and 2019 (Elimaki, 2016, p. 14). When the operating expense data of the sector in Table 4 is examined, it is seen that the sector average follows a flat course over the years. Therefore, it is thought that the expected decrease in operating expenses did not occur in the retail sector. Table 5 shows the effect of TFRS 16 standard on financing expenses.

Table 5. Analysis of TFRS 16 Impact on Financing Expenses

\begin{tabular}{cccc}
\hline & Mean & Minimum & Maximum \\
\hline 2018 & 6,3877 & 4,10 & 8,43 \\
2019 & 6,7549 & 4,97 & 8,76 \\
\hline
\end{tabular}


As it was stated before operating expenses will be separated into deprecation and interest expenses. Interest expense is recognized as financial expense in the statement. Therefore It is expected to have an increase in the financial expense with the application of TFRS 16 (Gökten and Kurnaz, p. 2020). When the data in Table 5 are examined, it is seen to be in an increasing trend in general. This result is consistent with the expectations in the table 2. However, the Mann-Whitney $U$ test conducted to determine whether the difference was significant or not and it was concluded that the difference between 2018 and 2019 was not statistically significant $(U=51.00, p=0.533>0.05)$. This result is compatable with Elimika's findings. Elimika (2016) forcasted that with the application of IFRS 16, it doesn't seem to be a significant increase in financial expense. Döğüş and Üçoğlu (2021) also found that there is no significant increase in financial expenses with the application of TFRS 16 in 2019, compared to 2018 data for the sectors such as manufacturing, transportation, storage and telecommunication. In order to examine the effect of TFRS 16 on the financial ratios, first the asset turnover averages were compared in Table 6.

Table 6. Analysis of TFRS 16 Impact on Asset Turnover

\begin{tabular}{cccc}
\hline & Mean & Minimum & Maximum \\
\hline 2018 & 2,721 & 0,451 & 5,766 \\
2019 & 1,81 & 0 & 3,963 \\
\hline
\end{tabular}

When the data in Table 6 are examined, it is seen that the average of enterprises decreased in 2019 compared to 2018 data. As rental assets are included into the total asset, it is expected that asset turnover rate will decrease. It is because while the sales remain the same in the numerator, total assets in the denumerator will increase and this will cause the ratio decrease (IFRS, 2016, p. 53). However, the Mann-Whitney $U$ test conducted to determine whether this difference is statistically significant, it was found that there was no significant difference between 2018 and $2019(U=43.00, p=0.250>0.05)$. Table 7 includes financial leverage analysis.

Table 7. Analysis of TFRS 16 Impact on Financial Leverage Ratio

\begin{tabular}{cccc}
\hline & Mean & Minimum & Maximum \\
\hline 2018 & 0,732 & 0,216 & 1,135 \\
2019 & 0,774 & 0,13 & 1,166 \\
\hline
\end{tabular}

With the application of TFRS 16, long and short term liabilities are expected to increase. With the increase in liabilities, it is also expected that financial leverage ratio will increase (Akdoğan and Doğan, 2020, p. 189). When Table 7 is analyzed, there is an increase in the financial leverage ratio in 2019 compared to 2018. This result is similiar to expectation in Table 2. However, as a result of the analysis made to determine whether the increase in 
question was statistically significant, it was concluded that the difference wasn't statistically significant ( $U=54.00, p=0.670>0.05)$. In thier work, Döğüş and Üçoğlu (2021) also found out that financial leverage didn't go up noticeably for the sectors such as information technology, transportation, storage and telecommunication sector. The effect of TFRS 16 on the rate of return on assets is given in Table 8.

Table 8. Analysis of TFRS 16 Impact on Return of Assets Ratio

\begin{tabular}{cccc}
\hline & Mean & Minimum & Maximum \\
\hline 2018 & 0,649 & $-7,67$ & 8,496 \\
2019 & 0,293 & $-9,82$ & 8,073 \\
\hline
\end{tabular}

The return of assets ratio is more likely to decrease because assets will increase considerably (because of capitalization of the leases) while the effect on income may be milder (Yampuler, 2020, p. 2). When the average data in Table 8 are analyzed, it is seen that the rate of return on assets has decreased. This decline was similar to the expectation list in table 2. The Mann-Whitney $U$ test was conducted to determine whether the difference in question was statistically significant or not. As a result of the test, it was concluded that the difference was not statistically significant $(U=51.00, p=0.778>0.05)$. Döğüş and Üçoğlu (2021) and Parlak (2018) similarly also found statistically insignificant decline in their works for all sectors. Table 9 shows the debt-equity ratio analysis.

Table 9. Analysis of TFRS 16 Impact on Debt-Equity Ratio

\begin{tabular}{cccc}
\hline & Mean & Minimum & Maximum \\
\hline 2018 & 9,063 & 0,276 & 48,744 \\
2019 & $-14,37$ & $-213,4$ & 43,78 \\
\hline
\end{tabular}

In TFRS 16, companies with operating leases will have to capitalize those leases as finance leases, recognizing a right-of-use asset aganist a long term lease liabilities. The amount added to assets and liabilities will be the same and will equal the discounted future lease payments. Equity is not expected to change due to this capitalization (Yampuler, 2020, p. 2). Therefore, the debt to equity ratio is expected to increase. When Table 9 is evaluated, it is seen that the debt-equity ratio is negative due to the negative equity statements of the enterprises in 2019. Therefore, contrary to the expectations in the Table 2, a decrease in the debt-equity ratio has been determined.

\section{Conclusion}

In Turkey, from January 1 2019, TMS 17 Standard has been abolished and TFRS 16 Leasing Standard has been put in force. With the new standard, businesses started to reflect their operating lease transactions in financial statements. Therefore, it is expected that there will 
be significant changes in the financial indicators of the companies after TFRS 16. IASB was aimed to evaluate the effect of TFRS 16 on businesses and sectors. Therefore it carried out impact analysis in 2015. As a result of this study, it has been determined that the financial statements of companies in the retail sector will be among the companies that will be most affected after TFRS 16.

When the studies in the literature are examined, it is seen that most of the studies are trying to determine the future effect of TFRS 16 on the financial statements. With this study, it is attempted to determine whether financial results similar to the expectations in the Table 2 have actually occurred or not. 2018 and 2019 financial indicators have been compared and the Mann-Whitney $U$ test was conducted to determine whether the differences between years were statistically significant.

As a result of the analysis, it is seen that the changes in the literature in some financial indicators (operating expenses, debt-equity ratio) are not realized, while the changes in some financial indicators are not significant (size of the statement of financial position, financing expenses, asset turnover rate, financial leverage ratio, return on assets. rate). Therefore, it is seen that the changes that have occurred are not realized as expected. It is thought that the reason why the expected changes are not observed may be due to the rapid increase in other cost elements belonging to the sector (KPMG, 2020).

When the IAS 17 standard was in effect, operating lease was not reflected in the financial statements. This causes negative cansequences. Particularly during economic downturns, companies face real difficulties since they can't see the debt load caused by operating lease in their financial statements clearly. TFRS 16 will bring transparent and reliable information not for only companies applying this new standard but also for all stakeholders who had wanted to make sound financial decisions about companies. Therefore, further studies are needed to depict consequences of application of TFRS 16. It is necessary to conduct similar studies in different sectors and to obtain more information about the impact in question.

One of the most important limitations of the study arises from the fact that the data of a limited number of businesses in the retail sector can be reached. Including more businesses in the study and using parametric tests will provide more useful information in order to fully demonstrate the effect in question.

\section{Ethical Statement Information of the Article Titled As "The Effect of TFRS 16 Leases Standard on Financial indicators of Turkish Retailer Companies"}

This study has been prepared in accordance with the values of

"Research and Publication Ethics"

\begin{tabular}{l|l} 
Acknowledgement & The study is not a re-production of a paper or thesis-like work. \\
$\begin{array}{l}\text { Conflict of Interest } \\
\text { Statement }\end{array}$ & $\begin{array}{l}\text { I assure as the author that there is no conflict or interest with third } \\
\text { parties. }\end{array}$
\end{tabular}




\begin{tabular}{l|l}
$\begin{array}{l}\text { Author } \\
\text { Contributions }\end{array}$ & I declare that I prepared the study myself as Erkin Nevzat GÜDELCl. \\
$\begin{array}{l}\text { Support } \\
\begin{array}{l}\text { Ethics Committee } \\
\text { Certificate Of } \\
\text { Approval }\end{array}\end{array}$ & Ethics committee approval is not required for the study. \\
\hline
\end{tabular}

\section{References}

Akbulut, D. H. (2018). Faaliyet Kiralaması İşlemlerinin Aktifleştirilmesinin Finansal Tablolara Ve Finansal Oranlara Etkisi Üzerine Bir Telekomunikasyon Şirketinin Vak'a Incelemesi. Muhasebe ve Finansman Dergisi, (78), 17-36.

Akdoğan, N., Erhan, D. U. (2020). TFRS 16 Kiralamalar Standardının Finansal Tablolar Üzerine Etkisi Ve Perakendecilik Sektörü Üzerine Bir Araştırma. Muhasebe Bilim Dünyası Dergisi, 22(1), 164-191.

Alabood, E., Abuaddous, M., Bataineh, H. (2019). The Impact Of IFRS 16 On Airline Companies: An Exploratory Study in The Middle East. International Journal of Economics and Business Research, 18(1), 112-128.

Deloitte. (2017). UFRS 16 Kiralama İşlemleri https://www2.deloitte.com/content/ dam/Deloitte/tr/Documents/the-deloitte-times/UFRS-16-kiralama-islemleri.pdf erişim tarihi: 12.10 .2018

Döğüş, Y., Üçoğlu, D. (2021). UFRS 16 Kiralamalar Standardının İlk Uygulamasının BiST'te İşlem Gören Şirketler Üzerindeki Finansal Etkileri. Muhasebe Ve Vergi Uygulamaları Dergisi, 14(2), 511-539.

Elimaki, P. (2016). Transition To IFRS 16 Leases And Its Impact On Key Financial Ratios For Construction Companies In Finland. Haage-Helia University (unpublished doctorate dissertation). Finland

Engin, A. (2016). Yeni (önerilen) Kiralama Iş̧lemleri Standardı Ve Değişikliğin Mali Tablolara Muhtemel Etkileri. Vergi Dünyası, 35 (420), 23-34

Giner, B., Pardo, F. (2018). The Value Relevance Of Operating Lease Liabilities: Economic Effects of IFRS 16. Australian Accounting Review, 28(4), 496-511.

Gökgöz, A. (2019). TFRS 16 Kiralamalar Standardı Çerçevesinde Kiralama İşlemlerinin Muhasebeleştirilmesi. Journal of Accounting, Finance and Auditing Studies, 5(1), 318-332.

Gökten, S., Kurnaz. G. A. (2020). UFRS 16 Kiralamalar Standardının Kiracının Finansal Tabloları Üzerine Etkileri: Seçilmiş Hava Yolu İşletmelerinde Bir İnceleme, İşletme Araştırmaları Dergisi, 2(2), 1848-1860 
Hazır, Ç. A. (2019). TFRS 16 Kiralamalar'ın Grup İçi Muhasebe Politikaları Çerçevesinde Değerlendirilmesi. Muhasebe ve Finansman Dergisi, (82), 55-76.

Hladika, M., Valenta, I. (2018). Analysis Of The Effects Of Applying The New IFRS 16 Leases On The Financial Statements. Economic and Social Development: Book of Proceedings, 255-263.

Hoogervorst, H. (2016). Introductory Comments To The European Parliament. https://www.ifrs.org/-/media/feature/news/speeches/2016/hans-hoogervorstintroductory-comments-to-the-european-parliament-jan-2016.pdf erişim tarihi: 05.10.2020

IASB. (2016). IFRS 16 lease. https://www.slideshare.net/sazzad128/basis-for-conclusionsinternational-financial-reporting-standard-january-2016-ifrs-16-leases. erişim tarihi: 14.10 .2020

IFRS 16 (2016) Leases Effects Analysis International Financial Reporting Standard, https://www.ifrs.org/-/media/project/leases/ifrs/published-documents/ifrs16effects-analysis.pdf

İslamoğlu, H., Alnıaçık, Ü. (2016). Sosyal Bilimlerde Araştırma Yöntemleri (Spss Uygulamalı). İstanbul: Beta

iSMMMO. (2019). TFRS 16 Kiralamalar: Yenilenen Kiralama Muhasebesi, Açıklama Ve Örneklerle İşletmelere Olası Etkileri. http://archive.ismmmo.org.tr/ YAYINLAR/e_kitap/tfrs_16_kiralamalar.pdf erişim tarihi: 30.09.2020

KGK, (2020). Finansal Raporlamaya illişkin Kavramsal Çerçeve, https://www.kgk.gov.tr/Portalv2Uploads/files/Duyurular/v2/TFRS/

Finansal\%20Raporlamaya\%20\%C4\%BOli\%C5\%9Fkin\%20Kavramsal\%20\%C3\%87er\% C3\%A7eve\%20.pdf erişim tarihi:30.09.2020

KGK. (2020). Kiralamalar. https://www.kgk.gov.tr/Portalv2Uploads/files /Duyurular /v2/ TFRS/FRS_16.pdf erişim tarihi:7.10.2020

KPMG. (2020). Sektörel Bakış, https://assets.kpmg/content/dam/kpmg/tr /pdf/2020 /01/ sektorel-bakis-2020-perakende.pdf erişim tarihi 29.03.2021

Kramarova, K. (2020). The Concept Of Operatıng Lease İn Terms Of The National Legislation And The IFRS 16 With Selected Impacts On Economy Of A Company. Economic and Social Development: Book of Proceedings, 135-144.

Levanti, D. A. (2019). IFRS 16 "leases"-financial Statements Disclosures For Credit Institutions. Ecoforum Journal, 8(3). 51-56

Magli, F., Nobolo, A., Ogliari, M. (2018). The Effects On Financial Leverage And Performance: The IFRS 16. International Business Research, 11(8), 76-89. 
Merve, A., Temiz, H., Aktaş, R. (2013). UMS 17 Kiralama İşlemleri Standardından Ufrs 16’ya Geçişin Finansal Tablolar Üzerinde Etkisi: Borsa İstanbul Örneği. Muhasebe Bilim Dünyası Dergisi, 19(3), 592-623.

Morales-Díaz, J., Zamora-Ramírez, C. (2018). The Impact Of IFRS 16 On Key Financial Ratios: A New Methodological Approach. Accounting in Europe, 15 (1), 105-133.

Özdoğan, B., Uygun, U. (2020). TMS 17 Kiralama İşlemleri Standardından Tfrs 16 Kiralamalar Standardına Geçişte Bist Şirketlerine Yönelik Sektörel Etkilerin Karşılaştırmalı Analizi. Manisa Celal Bayar Üniversitesi Sosyal Bilimler Dergisi, 18(2), 209-227.

Öztürk, M., Serçemeli, M. (2016). Impact of New Standard "IFRS 16 Leases" on Statement of Financial Position and Key Ratios: A Case Study on an Airline Company in Turkey. Business and Economics Research Journal, 7(4), 143.

Parlak, N. (2018). Kiralama işlemlerinin UMS 17 ve UFRS 16 Standartlarına Göre Karşılaştırılmalı Olarak İncelenmesi Ve Şirketlerin Finansal Durumuna Etkisi. Hitit üniversitesi Sosyal Bilimer Enstitüsü (yayınlanmamış doktora tezi). Çorum

PWC. (2016). IFRS 16: The Leases Standard is Changing, Are You Ready? https://www.pwc.com/gx/en/services/audit-assurance/assets/ifrs-16-newleases.pdf erişim tarihi: 12.10 .2020

Quach, V., Tu, L. (2020). Implications Of Accounting Standard Changes For Financial Reports: An Exploratory Study Of The Transition To Ifrs 16, Master Degree Project, University of Gothenburg, Sweden

Sacarin, M. (2017). IFRS 16 "leases"-Consequences On The Financial Statements And Financial Indicators. The Audit Financial Journal, 15(145), 114-122.

Sarı, E. S., Altintas, T., Tas, N. (2016). The Effect Of The IFRS 16: Constructive Capitalization Of Operating Leases in The Turkish Retailing Sector. Journal of Business Economics and Finance, 5(1), 138-147.

Spånberger, J., Rista, M. (2020). Implications Of Ifrs 16 Adoption: Evidence From Swedish Publicly Listed Firms, Master Thesis, Uppsala University, Sweden

Ssarı, E. S., Güngör, N. (2020). TFRS 16 Standardının Seçilmiş BiST 100 Şirketlerinin Finansal Tabloları Ve Finansal Performanslarına Etkisinin İncelenmesi. Anadolu Üniversitesi Sosyal Bilimler Dergisi, 20(3), 287-312.

Stancheva Todorova, E., Velinova Sokolova, N. (2019). IFRS 16 Leases And its Impact On Company's Financial Reporting, Financial Ratios And Performance Metrics. Economic Alternatives, 1(2019), 44-62.

Stefan, B. (2017). Analysis of Conceptual And Technical (In) Consistencies in The Ifrs 16 Leases Accounting Model. Annals of Faculty of Economics, 1(1), 247-258. 
Tănase, A. E., Calotă, T. O., Oncioiu, F. R. (2018). The Impact Of IFRS 16 On The Companies' Key Performance Indicators: Limits, Advantages And Drawbacks. Academic Journal of Economic Studies, 4(1), 54-59.

Veverková, A. (2019). IFRS 16 And its Impacts On Aviation Industry. Acta Universitatis Agriculturae et Silviculturae Mendelianae Brunensis, 67(5), 1369-1377.

Yampuler, M. (2020). The Effect Of The Recent IFRS 16 On Major Financial Statements' Ratios. Strategies in Accounting and Management, 1(3), 1-3

You, J. (2017). The Impact Of Ifrs 16 Lease On Financial Statement Of Airline Companies, Doctoral dissertation, Auckland University of Technology, New Zealand

Yürekli, E. (2019,Nisan). TFRS 16 Kiralamalar Standardı Ve Finansal Tablolara Etkisi. International Applied Social Sciences Congress, lasos Congress, 04-06 April 2019 Çeşme/izmir.

www.sheffield.ac.uk/polopoly_fs/1.714552!/file/stcp-marshall-MannWhitS.pdf,

Access date: 09.17.2021 